This is an open access article under the terms of the CC-BY 3.0 License.

Peer review method: Double-Blind

Date of acceptance: September 16, 2020

Date of publication: November 11, 2020

Original scientific article

DOI: https://www.doi.org/10.47305/JLIA2060030b

\title{
QUESTIONING DEFENDANTS VIA SKYPE DURING THE STATE OF EMERGENCY IN THE REPUBLIC OF SERBIA
}

\author{
Aleksandar Bošković \\ University of Criminal Investigation and Police Studies, Belgrade, Republic of Serbia \\ aleksandar.boskovic@kpu.edu.rs \\ Tanja Kesić \\ University of Criminal Investigation and Police Studies, Belgrade, Republic of Serbia \\ ORCID iD: https://orcid.org/0000-0001-9473-4379 \\ tanja.kesic@kpu.edu.rs
}

\begin{abstract}
The state of emergency was declared in the Republic of Serbia on 15 March 2020, due to the COVID-19 pandemic, which lasted until 6 May 2020. During the state of emergency, certain human rights were restricted and suspended, which are otherwise protected and guaranteed by the Constitution. One of the measures introduced by the state was the possibility for the defendant to attend the main hearing via Skype. The basic question arises whether the right to a fair trial is violated in this way, since it is one of the rights that cannot be limited or suspended even during a state of emergency. In this regard, this paper addresses the national legal framework under which trials are permitted and conducted via Skype during a state of emergency and relevant case law of the European Court of Human Rights.
\end{abstract}

Keywords: Questioning; Defendant; Skype; Fair Trial; COVID-19 


\section{INTRODUCTION}

The situation caused by the COVID-19 pandemic has reached dramatic proportions worldwide. Currently, over 14.5 million people have been infected across the world, and over 600 thousand people have died from this virus so far (Worldometer 2020). Bearing in mind all the consequences that occur with the spread of this dangerous virus, it is clear that many countries have resorted to various methods and applied various measures in order to combat the infection. As a last resort, a number of countries had declared a state of emergency in the fight against the coronavirus, given the level of the danger threatening the survival of the state and its citizens. The Republic of Serbia was one of those countries.

In the Republic of Serbia, the state of emergency was declared on 15 March 2020 by a joint decision of the President of Serbia, the President of the National Assembly, and the Prime Minister (Decision on declaring a state of emergency, Official Gazette of the RS, No. 29/2020). It should be pointed out that this decision on declaring a state of emergency in the Republic of Serbia derogates from the general rule set forth by the Constitution of the Republic of Serbia. Specifically, under the provisions of the Constitution of the Republic of Serbia (Official Gazette of the RS, No. 98/2006), the National Assembly may declare a state of emergency when public danger threatens the survival of the state or its citizens (Article 200, paragraph 1) by a majority vote of all deputies (Article 105, paragraph 2, item 2). On the other hand, only if the National Assembly is unable to meet, the decision to declare a state of emergency is reached jointly by the President of the Republic, the President of the National Assembly, and the Prime Minister, under the same conditions as the National Assembly (Article 200, paragraph 5). Therefore, the government body primarily responsible for declaring and lifting a state of emergency is the National Assembly, and only in the case when the National Assembly is unable to meet, which is a factual issue, the decision is reached jointly by President of Serbia, the President of the National Assembly, and the Prime Minister. It is important to mention that the Constitution does not specify a body responsible for evaluating whether the National Assembly is unable to meet, and this issue is of great importance because the application of these constitutional alternative provisions depends on it. ${ }^{1}$ Declaring a state of emergency creates a possibility for restricting and suspending certain human rights for a certain period of time. Thus, the Constitution of the Republic of Serbia prescribes that by declaring a state of emergency, the National Assembly may prescribe measures derogating from the human and minority rights guaranteed by the Constitution (Article 200, paragraph 4). One of the

\footnotetext{
${ }^{1}$ For a detailed analysis of this issue, as well as the issue of the constitutionality of the decision to declare a state of emergency, see: Darko Simović, "Vanredno stanje u Srbiji: ustavni okviri praksa povodom pandemije COVID-19", Fondacija Centar za javno pravo, 2020, pp. 3-15, http://fcjp.ba/analize/Darko Simovic10-Vanredno stanje u Srbijiustavni okvir i praksa povodom pandemije COVID-19.pdf [Accessed: 1 July 2020].
} 
characteristics of the state of emergency is that it allows for derogation from the regular human rights regime in order to overcome the extraordinary circumstances as effectively as possible and restore public order which has been disturbed (Simović 2020).

Given that the state of emergency was not declared by the National Assembly because the Assembly was unable to meet, measures derogating from human and minority rights may be prescribed by the Government, by decree, with the co-signature of the President of Serbia (Article 200, paragraph 6). The aforementioned constitutional provision has found its application. In other words, during the state of emergency in the Republic of Serbia, which lasted until 6 May2020, ${ }^{2}$ measures derogating from human and minority rights were enacted by the Government, with the co-signature of President of Serbia.

With respect to derogations from human and minority rights during a state of emergency, the Constitution stipulates that following the declaration of a state of emergency, these derogations are allowed only to the extent necessary (Article 202, paragraph 1). Additionally, derogation measures must not lead to discrimination on the basis of race, sex, language, religion, nationality or social origin (Article 202, paragraph 2) and cease to be valid upon the lifting of the state of emergency (Article 202, paragraph 3). Therefore, the measures of derogation from human and minority rights cannot last longer than the state of emergency, but they can certainly last shorter and should always be aimed at achieving certain necessary goals in the shortest possible time, which concern the survival of the state or its citizens. However, there are certain rights that cannot be restricted or revoked even during the state of emergency. The Constitution of the Republic of Serbia exhaustively lists the rights that cannot be derogated from. ${ }^{3}$

Considering the rights guaranteed by the Constitution from which no deviations are allowed and the topic of this paper, our research addresses the national legal framework under which Skype trials are allowed and conducted during the state of emergency and the relevant case law of the European Court of Human Rights regarding

\footnotetext{
${ }^{2}$ At the session held on 6 May 2020, the National Assembly of the Republic of Serbia enacted the Decision on lifting the state of emergency (Official Gazette of the RS, No. 65/2020), which entered into force on the day of its publication, that is, on the same day, while at a previous session held on 29 April 2020, the National Assembly passed the Decision on confirming the Decision on declaring the state of emergency (Official Gazette of the RS, No. 62/2020). ${ }^{3}$ Article 202, paragraph 4 of the Constitution of the Republic of Serbia stipulates that derogation measures are in no case allowed with regard to the following guaranteed rights: the right to dignity and free development of personality (Article 23), the right to life (Article 24), the inviolability of the physical and mental integrity (Article 25), the prohibition of slavery, positions similar to slavery and forced labor (Article 26), the right of persons deprived of liberty to fair treatment (Article 28), the right to a fair trial (Article 32), legal certainty in criminal law (Article 34), the right to legal personality (Article 37 ), the right to citizenship (Article 38), the right to freedom of thought, conscience and religion (Article 43), conscientious objection (Article 45), freedom of expression (Article 47), the prohibition of incitement to racial, national and religious hatred (Article 49), the right to marry and the equality of spouses (Article 62), the freedom of birth-decision (Article 63), the rights of the child (Article 64), and the prohibition of forced assimilation (Article 78).
} 
the possibility for the defendant to attend the main hearing without being physically present in the courtroom, and the issues of whether trials by Skype have led to the restriction of the defendant's certain rights, which should not have been restricted even during the state of emergency and whether the right to a fair trial, as one of the defendant's basic rights, was infringed in this way, which cannot be restricted even during the state of emergency.

\section{QUESTIONING DEFENDANTS VIA SKYPE: NATIONAL LEGAL FRAMEWORK DURING THE STATE OF EMERGENCY}

The defendant is a fundamental participant in a criminal process, who performs the function of defense and has the status of a party to criminal proceedings, who is under suspicion of having committed an offence and against whom criminal proceedings are conducted (Bošković and Kesić 2015, 75). The questioning of defendants is a very important general evidentiary action in criminal proceedings, which is regulated by the provisions of Articles $85-90$ of the Criminal Procedure Code of the Republic of Serbia (Official Gazette of the RS, Nos. 72/2011, 101/2011, 121/2012, $32 / 2013,45 / 2013,55 / 2014$, and 35/2019). In terms of content, the hearing of the defendant consists in the defendant's giving a statement with respect to the criminal offense he/she has been charged with (the defendant's active defense) or in refraining from giving a statement (the defendant's passive defense), if he chooses to remain silent and not testify in his/her defense, after he/she has been warned of his/her duties in criminal proceedings, he/she has been given the opportunity to testify (Škulić 2018, 202). During the criminal proceedings, the defendant ${ }^{4}$ can be interview several times in different stages and phases: during pre-investigation, investigation, and at the main hearing. In the preliminary proceedings (pre-investigation and investigation), the defendant may be questioned by the public prosecutor and, with the prosecutor's approval, by the police with the fulfillment of the conditions prescribed by the Criminal Procedure Code - CPC (Bošković and Kesić 2015, 220). However, the aim of our analysis is the questioning and attendance of the defendant at the main hearing conducted via Skype during the state of emergency, meaning the defendant was not physically present in the courtroom during the main hearing.

Considering the provisions of the CPC regulating the questioning of the defendant at the main hearing at the first instance court, it can be noticed that the CPC insists that the defendant be physically present while being questioned. Specifically, there is no legal possibility for the defendant, for example, to be interviewed through videoconference or other audio and video links at the main hearing. The primary goal of

\footnotetext{
${ }^{4}$ The term defendant is also used to refer to a suspect, accused, defendant or convicted person (Article 2, paragraph 1 , item 2 of the $C P C)$.
} 
the physical presence requirement in courtroom proceedings is to provide the defendant and judge with unique benefits that are unavailable in a video teleconference (Annet 2019, 168). Those benefits include the ability to prevent an adverse inference from the lack of an appearance, the attention to non-verbal cues and the ability for the defendant to personally interact with defense counsel (Annet 2019, 168). Physical presence of the defendant at the trial is also important because CPC gives priority to adversarial principle over previously dominant principle of establishing the material truth (Ćetković; Kesić; Bjelovuk 2017, 82). A possibility to be interviewed through video conference or other audio and video links at the main hearing is envisaged for the examination of a particularly sensitive or protected witness, ${ }^{5}$ but it is not envisaged for the questioning of accused persons. However, regarding the attendance of the defendant at the main hearing, that is, his physical presence in the courtroom, the CPC provides that the defendant may be removed from the courtroom under certain conditions. Specifically, if the defendant disrupts the trial by disobeying orders from the presiding judge or insults the dignity of the court, the presiding judge will warn him, but if the defendant continues his/her disruptive behavior, he/she may be fined (Article 370, paragraph 1 of the CPC). However, if these imposed measures are unsuccessful, the panel of judges may remove the defendant from the courtroom during the undertaking of certain evidentiary actions, and if upon returning to the courtroom the accused continues his/her disruptive behavior, the panel of judges may remove him/her from the evidentiary proceedings and order, if there is such a possibility, that the accused follow the course of the proceedings from a special room through audio-video electronic means (Article 371, paragraph 1 of the CPC). Therefore, regarding the first instance proceedings, we can conclude that the CPC does not provide for the possibility of questioning defendants through any audio-visual means. On the other hand, concerning the attendance of the defendant at the main hearing, it is possible, under the aforementioned conditions, to remove the defendant from the courtroom, who may follow the entire evidentiary proceedings from a special room through audio-video electronic means.

However, with respect to the second instance proceedings, the CPC is even more specific regarding the attendance of the defendant at the hearing before the second instance court and it essentially allows this possibility. Specifically, the hearing at the second instance court is held if it is deemed necessary to present evidence that had already been presented or rejected by the first instance court due to erroneously or incompletely established factual situation, and there are justified reasons not to return the case to the first instance court (Article 449, paragraph 1). The subpoena will warn the

\footnotetext{
${ }^{5}$ For example, the CPC envisages that a particularly sensitive witness be examined through audio-video electronic means (Article 104, paragraph 2 of the CPC) or that a protected witness may be examined in a special room with a choice to modify the image of face of the witness and to change the audio feed of the witness's voice so that he/she is not identifiable (Article 108, paragraph 2 of the CPC).
} 
defendant that the hearing will be held in his absence, if he is duly summoned, but does not justify his absence, the court will then appoint a defense attorney ex officio for the defendant who does not have a defense attorney (Article 449, paragraph 3). As it can be seen, the aforementioned provision of the CPC stipulates that the hearing before the second instance court may be held in the absence of the defendant if he/she is duly summoned but does not justify his/her absence, with the provision of ex-officio defense attorney. This possibility does not exist in the first instance proceedings. Furthermore, if the accused is in custody or serving a prison sentence, the presiding judge of the court of second instance shall undertake the necessary actions to bring the accused to trial, and when the panel finds that securing the presence of the accused is difficult for security or other reasons, the accused may attend the hearing through audio-video electronic means if it is possible to conduct a remote hearing (Article 449, paragraph 4). From the aspect of the topic of this paper, this provision of the CPC is very important because it enables the accused person to attend the hearing through audio-video electronic means. The reasons that may lead to this situation are of a security nature, but there can be other reasons if, in a given case, the panel concludes that the reason is of such a nature that it is better and more expedient for the accused to attend the main hearing via video-link, which represents a factual question. The fact is that the aforementioned provisions refer to the appeal proceedings, but it may be concluded that the attendance of the defendant at the main hearing through live link is not absolutely excluded, in other words, it is allowed under certain conditions.

In addition to the provisions of the CPC, as the umbrella law in the state which regulates the rules of criminal procedure, other decisions important for the actions of courts and public prosecutor's offices were enacted during the state of emergency. As already mentioned, the state of emergency was declared on 15 March 2020, while on 17 March the Ministry of Justice issued Recommendations for the work of courts and public prosecutors' offices during the state of emergency (Ministry of Justice, No. 112-01557/2020-05 of17 March 2020). This act recommends, among other things, that in criminal cases the competent courts and public prosecutor's offices process criminal cases in which custody is ordered or custody is requested, as well as criminal cases involving offenses of illicit trade (Article 235 of the Criminal Code), failure to act according to health regulations during epidemics (Article 248 of the Criminal Code) and transmission of infectious diseases (Article 249 of the Criminal Code). As regards other cases, the main hearings and the conduct of the pre-trial proceedings are postponed (Recommendation of the Ministry of Justice, item 6). In this way, the urgency of handling cases during the state of emergency is pointed out, especially regarding the aforementioned criminal offenses. These Recommendations are in a way confirmed by the Conclusion of the High Judicial Council (Conclusion of the High Judicial Council, No. 119-05-132/2020-01 of 18 March 2020) which stipulates that during the state of emergency only trials that cannot be postponed such as hearings involving the 
aforementioned offenses, while for all other offenses the main hearings are postponed. However, the issue of the attendance of the defendant at the main hearing via Skype was not in any way regulated by the Recommendations of the Ministry of Justice and Conclusion of the High Judicial Council.

With respect to the topic of this paper, a very important act to consider is a letter from the Ministry of Justice dated 26 March 2020, sent to the courts that are to conduct proceedings against persons who have violated self-isolation/quarantine measures, ordering them to conduct proceedings via video-link. ${ }^{6}$ The courts were suggested to install the Skype application on to the computers, and, as specified, both the employees and those against whom the proceedings are being conducted would be thus protected (Zoric 2020).

Factually, with this letter, the Ministry of Justice recommends that the accused, who is in custody, not be brought to trial for violating self-isolation measures, but to remain in custody and communication with him/her shall be established via video link, that is, Skype. The reason the Ministry of Justice enacted this act lies in the fact that during that period, a large number of people violated the self-isolation measure. Specifically, as of 16 March, all persons returning to Serbia had been required to selfisolate (quarantine at home) and stay at home for a minimum of 14 days. Any person who violates this measure commits the offense of non-compliance with health regulations during epidemics (Article 248 of the Criminal Code); given the difficult epidemiological situation and the state of emergency declared, a way to effectively conduct criminal proceedings regarding the violation of these measures was sought. ${ }^{7}$

A few days later, that is, on 1 April, the Government of the Republic of Serbia, with the co-signature of the President of Serbia, passed a Decree on the manner the accused is to attend the main hearing in the criminal proceedings held during the state of emergency declared on 15 March 2020 (Official Gazette of RS, No. 49/2020) which fully, belatedly, complied with the provision of the Constitution stipulating that during the state of emergency, when the National Assembly is unable to meet, measures derogating from human and minority rights may be prescribed by the Government, by a decree co-signed by the President of Serbia (Article 200, paragraph 6 of the Constitution). The Decree contained only two articles, of which Article 2 referred to the question of its entry into force. The Decree stipulates that during the state of emergency declared on 15 March2020, when the presiding judge or a single judge finds that securing the presence of the accused being in custody at the main hearing, in the criminal proceedings before the first instance court, is difficult due to the risk of

\footnotetext{
${ }^{6}$ Note that this letter from the Ministry of Justice has never been made public.

${ }^{7}$ On the day this decision was enacted by the Ministry of Justice of the Republic of Serbia, 26 March 2020, 108 people had been in custody in Vršac, Pirot, and Požarevac for violating self-isolation measures, of which44 people had been held in custody in Vršac, 43 in Požarevac, and 21 in Pirot, http://rs.n1info.com/Vesti/a582123/Ministarstvo-pravdezbog-koronavirusa-uvodi-sudjenja-putem-Skajpa.html [Accessed: 10 July 2020].
} 
infectious disease transmission, they may reach a decision that the defendant's attendance at the main hearing be ensured through audio-video electronic means, provided that audio and video technology to conduct hearings is available (Article 1 of the Decree).

An analysis of this Decree reveals several facts. First, the criminal offenses this Decree refers to are not defined, nor does the Decree itself refer to any previously enacted regulation. Therefore, if we consider the provisions of the previously presented acts, the Recommendations of the Ministry of Justice for the work of courts and public prosecutors' offices during the state of emergency of 17 March and the Conclusion of the High Judicial Council of 18 March, it may be concluded that the application of this Decree is much broader and refers to all custody cases, and therefore to all criminal offenses rather than just to the criminal offenses of illicit trade (Article 235 of the CC), failure to comply with health regulations during epidemics (Article 248 of the CC), and the transmission of an infectious disease (Article 249 of the CC). However, this issue was resolved on 9 April, when the High Judicial Council adopted the Conclusion (Conclusion of the High Judicial Council, No. 021-05-00040/2020-01 of 9 April2020), which, in respect to the application of the aforementioned Decree, determined that the High Council found that it refers only to the accused persons held in custody for the offenses of illicit trade (Article 235 of the CC), failure to comply with health regulations during epidemics (Article 248 of the CC) and the transmission of infectious diseases (Article 249 of the (C), as well as that the application of the Decree should not be extended to other police custody cases (Conclusion of the High Judicial Council, No. 021-05-00040/202001 of 9 April 2020, paragraph II).

Furthermore, it can be noticed that conducting hearing through audio and video technology such as live links is not obligatory. In other words, the presiding judge or a single judge may decide to conduct a trial in this way, but they do not have to. This issue is of a factual nature and judges should consider it on a case-by-case basis, but it depends on their evaluation whether securing the presence of the accused, who is held in custody, at the main hearing is hampered by the risk of infectious disease transmission. Finally, this concerns only the cases in which the accused is held in custody and questioned via video link from a custody facility.

Taking into consideration the aforementioned provisions of the Constitution, the Criminal Procedure Code, numerous bylaws enacted by the executive authorities during the state of emergency, as well as the entire national legal framework within which the government authorities took actions during trials by video link, it is clear that many controversial issues and doubts have arisen around the constitutionality and legality of these actions, which is discussed in more detail in the following section. 


\section{CERTAIN DILEMMAS AND PROBLEMS}

Considering all the above, a number of issues arise regarding the legality and justification of the introduction of trials through live links during the state of emergency. One of the first issues that arises, which is perhaps the least controversial, is whether the Recommendation of the Ministry of Justice of 26 March 2020 is an appropriate legal basis on which the courts acted and conducted this type of trial. The same recommendation was in place until 1 April, when, in accordance with the Constitution, the appropriate Decree was enacted by the Government, with the co-signature of the President of Serbia. However, even during these several days, the judgments of convictions were rendered at trials by Skype, where the aforementioned Recommendation served as the legal basis. In this regard, it is pointed out that "the enactment of this decree confirms that the letter from the Ministry of Justice could not be the basis for trials by 'Skype', so it would be logical that such judgments be revoked because the presumption of iura novit curia applies to basic court judges, including those from Dimitrovgrad, Pozarevac, and Pancevo, who rendered judgments after the trials by 'Skype' which had been held prior to 1 April 2020, meaning that they are obligated to state the legal basis for the accused to attend the main hearing through video link in reasons for judgments" (llić 2020). The Serbian Bar Association also expressed a clear position on this issue in its letter to the Ministry of Justice of March 30, stating, among other things, that "this new measure introduced in our criminal procedure legislation by a simple letter from the Ministry of Justice to courts in the Republic of Serbia, cannot be a valid basis for its implementation", invoking the relevant provisions of the Constitution of Serbia (Letter of the Serbian Bar Association, No. 303/2020 of 30 March 2020). Considering the relevant provisions of the Constitution of Serbia already mentioned, it is clear that the mentioned letter of the Ministry of Justice is not an adequate legal basis for conducting trials through audio-video electronic means during the state of emergency; however, it was necessary for the Government to enact the Decree (which was done several days later) so that derogation from human rights during the state of emergency would be in accordance with the constitutional provisions.

One of the crucial questions is whether trials through audio-video electronic means during the state of emergency are legal. Is it allowed to conduct such trials in accordance with positive legal regulations and the case law of the European Court of Human Rights? It should be borne in mind that by declaring the state of emergency it is possible to derogate from the human rights guaranteed by the Constitution, with the exception of a certain range of rights that cannot be suspended or restricted even during the state of emergency. One of these rights is the right to a fair trial, so the essential question arises as to whether the right to a fair trial guaranteed by the Convention for the Protection of Human Rights and Fundamental Freedoms is violated 
in this way (llić 2020). In considering this issue, different arguments and understandings are presented. Thus, some commentators point out that

even during the state of emergency, the CPC does not provide for the possibility of derogating from the principle of immediacy and the principle of publicity, while the right of the individual who is on trial to attend the trial if he/she is available to government authorities and have a public trial is so important that it is guaranteed both by the Constitution of the Republic of Serbia and the Convention for the Protection of Human Rights and Fundamental Freedoms. It is not possible to limit these rights even during the state of emergency (Milić 2020).

Furthermore, the Serbian Bar Association "opposes to the introduction of trials by video link, that is, Skype as a procedural possibility which is not envisaged by the law, representing a drastic violation of the defendant's right to a fair trial" (Letter of the Serbian Bar Association, No. 303/2020 of 30 March 2020). It is also pointed out that "the Government of Serbia has suspended the provisions of Article 33, paragraph 4 of the Constitution of the Republic of Serbia and Article 13, paragraph 1 of the Criminal Procedure Code, which stipulate that anyone charged with a criminal offense shall be tried in his presence, and "the defendant who is available to the court may be tried only in his presence, except when trial in absentia is exceptionally allowed by this Code, which has led to a flagrant violation of the Constitution and creation of the conditions leading to the violation of the right to a fair trial" (Todorovic 2020).

However, this issue is much more complex and in such situations it is necessary to consult the case law of the European Court of Human Rights (EctHR), that is, to determine whether the EctHR permits, under certain conditions, trials to be conducted via audio-video electronic means without the defendant being physically present in the courtroom, who is in a custody facility. In the case of Marcello Viola v. Italy-Application no. 45106/04 (Judgment 5.01.2007), the question as to whether there was a violation of the right to a fair trial was considered, as an element of the right to a fair trial, because the accused attended the main trial via video link. Specifically, the appellant did not complain that he was prevented from following the proceedings. Rather, he complained about the manner of the conduct of proceedings, that is, the proceedings conducted a video link which created problems for his defense (para. 64). Although the participation of the accused in the proceedings through videoconference is not in itself contrary to the Convention, the court is obligated to ensure that the use of this measure serves a legitimate purpose and that the presentation of evidence is in accordance with the due process requirement set out in Article 6 of the Convention (para. 67). Unquestionably, the transfer of prisoners, in the given case, meant particularly strict security measures, as well as the danger of escape and attack. It would also provide him with the opportunity to renew contacts with suspected criminal organizations he is suspected of belonging to 
(para. 69). It is pointed out that the appellant's attorney had the right to be present at the place where his client was and conduct a confidential interview with him (para. 75). Finally, the Court found that the applicant's participation in the proceedings via videoconference did not place the defense in a subordinate position vis-à-vis the other party and that the defendant was given an opportunity to exercise his rights inherent in the concept of a fair trial, so there was no violation of Article 6 of the Convention (paras. 76-77).

At this point,it is useful to mention the position of the European Court of Human Rights in the case of Sakhnovskiy v. Russia - Application no. 21272/03 (Judgment November 2, 2010), according to which the use of video link, as a way of attending the proceedings, is not, as such, incompatible with a fair and public hearing, but the defendant must be allowed to follow the proceedings and be questioned without technical difficulty, as well as to be enabled to have confidential conversations with his legal representative (para. 98).

Thus, questioning the accused and monitoring the main hearing via video link, in essence, is not in contrary to the provisions of the Convention which regulate the right to a fair trial, that is, the right to a fair discussion as an integral part of the right to a fair trial. Certainly, holding trials by videoconference has its limitations and cannot become the standard in the regular conduct of criminal proceedings, beyond the state of emergency; therefore it is necessary to justify such an action with valid reasons. In this regard,

it is necessary to analyze the justification for the defendant's attendance at the main hearing through audio-video electronic means and explain why the defendant's attendance at the main hearing via video link does not diminish the guarantees contained in the right to a fair trial. It is necessary to consider the attendance of the accused at the main hearing via video link in the light of certain guarantees contained in the right to a fair trial in criminal proceedings and determine the criteria for evaluating difficulties in securing the presence of the accused at the main hearing (llić 2020).

\section{CONCLUSION}

The state of emergency was declared in the Republic of Serbia on 15 March 2020, due to the COVID-19 pandemic, which was lifted on 6 May 2020. The state of emergency was declared by a joint decision of the President of Serbia, the President of the National Assembly, and the Prime Minister. It should be noted that this decision on declaring the state of emergency in the Republic of Serbia derogates from the general rule set forth by the Constitution, because the decision on declaring a state of emergency may be passed jointly by President of Serbia, the President of the National Assembly, and the Prime Minister only if the National Assembly is unable to meet. 
Declaring a state of emergency creates the possibility of restricting and suspending certain human rights for a certain period of time only to the extent necessary. The Constitution of the Republic of Serbia exhaustively lists the guaranteed rights from which derogation are not allowed, among which is the right to a fair trial - the most controversial right with respect to the defendant's attendance at the main hearing via video link.

Considering the national legal framework, we can see that the CPC does not provide for the defendant to be questioned via video link or the possibility for the defendant to follow the main hearing out of court through audio-video electronic means, regarding the first instance proceedings, while in the second instance proceedings, the CPC, in principle, allows this possibility. The letter from the Ministry of Justice dated 26 March 2020, which was sent to the courts that are to conduct proceedings against persons who have violated the self-isolation measure and ordering the proceedings to be conducted via live link was not an appropriate legal basis for holding trials by Skype and this omission was eliminated on April 1 when the relevant Decree was enacted. Bearing in mind this omission, it should be assumed that all judgments of convictions rendered between 26 March and1 April 2020, when the previously mentioned recommendation of the Ministry served as a legal basis, will be revoked on appeal. The ECHR essentially allows the defendant to attend the main hearing via videoconference, but in such a way which does not place the defense in an inferior position in relation to the other party and the defendant is given an opportunity to exercise his rights inherent in the concept of a fair trial. Holding hearings via videoconference has its limitations and cannot become the standard in the regular criminal proceedings, beyond the state of emergency. It is necessary to justify such actions with valid reasons of which security reasons are certainly one of the most important reasons. Thus, it may be concluded that the attendance of the defendant at the main hearing via video conference is not illegal or contrary to the right to a fair trial guaranteed by the European Convention for the Protection of Human Rights and Fundamental Freedoms and the Constitution of Serbia. On the other hand, the use of this possibility should be understood as extremely restrictive and should not become a common practice. During trials via videoconference, the guaranteed rights of the defendant must be respected, especially the right to confidentiality. However, one question arises as to whether it was so necessary and urgent to handle these criminal offenses that judgments were rendered within one or two days. It is well known that the criminal proceedings in the Republic of Serbia take long, therefore it was possible to conduct the trial for the defendant after the state of emergency had been lifted, while the dangers to health could be eliminated by applying some measures to ensure the defendant's presence in the criminal proceedings or, as a last resort, by imposing a pretrial detention measure. 


\section{ACKNOWLEDGEMENTS}

This article is the result of the realization of the Scientific Research Project entitled 'Development of Institutional Capacities, Standards and Procedures for Fighting Organized Crime and Terrorism in Climate of International Integrations'. The Project is financed by the Ministry of Education, Science and Technological Development of the Republic of Serbia (No. 179045), and carried out by the University of Criminal Investigation and Police Studies in Belgrade (2011-2020). 


\section{REFERENCES}

1. Aleksandar, Bošković and Tanja, Kesić. 2015. Krivično procesno pravo. Kriminalističko-policijska akademija. Beograd.

2. Annet, Meaghan. 2019. "To Be Physically Present or Not to Be Physically Present: The Use of Videoconferences During Felony Proceedings." Boston College Law Review 9:165-179. Accessed June 10, 2020.http://lawdigitalcommons.bc.edu/bclr/vol60/iss9/12

3. Darko, Simović. 2020. Vanredno stanje u Srbiji: ustavni okvir i praksa povodom pandemije COVID-19, Sveske za javno pravo (BlätterfürÖffentlichesRecht), Fondacija Centar za javno pravo, str. 3-15. Dostupno na: http://fcjp.ba/analize/Darko Simovic10-Vanredno stanje u Srbijiustavni okvir i praksa povodom pandemije COVID-19.pdf dana 01.07.2020. godine.

4. Dopis Advokatske komore Srbije, br. 303/2020 od 30.03.2020.

5. Goran, P. Ilić. 2020. Virus neznanja nikad ne spava. dostupno na: https://otvorenavratapravosudja.rs/teme/ustavno-pravo/virus-neznanja-nikadne-spava dana 08.07.2020

6. Jovica, Todorović. 2020. Malograđanski duh u građanskom odelu. dostupno na: https://boljaadvokatura.com/malogradanski-duh-u-gradanskom-odelu/ 10.07.2020.

7. Milan, Škulić. 2018. Krivično procesno pravo. Univerzitet u Beogradu - Pravni fakultet, Beograd.

8. Odluka o potvrđivanju Odluke o proglašenju vanrednog stanja, "Službeni glasnik RS", br. 62/2020.

9. Odluka o proglašenju vanrednog stanja, "Službeni glasnik RS", br. 29/2020.

10. Odluka o ukidanju vanrednog stanja, "Službeni glasnik RS", br. 65/2020.

11. Predrag, Ćetković, Tanja, Kesić, Ivana, Bjelovuk. 2017. "Pravnonedopuštenidokazi u krivičnompostupku. Teorijaplodovaotrovnogdrveta". Pravniživot10:81-95.

12. Preporuke za rad sudova i javnih tužilaštava za vreme vanrednog stanja, Ministarstvo pravde, br. 112-01-557/2020-05 od 17. marta 2020.

13. Presuda u predmetu Marcello Viola v. Italy - Application no. 45106/04 (Judgment 5.01.2007available at: http://hudoc.echr.coe.int/eng?i=001-77246 visited: 10.07.2020.).

14. Presuda u predmetu Sakhnovskiy v. Russia - Application no. 21272/03 (Judgment 2.11.2010available at: http://hudoc.echr.coe.int/eng?i=001-91130 visited: 12.07.2020).

15. Trickovic Sasa, 2020, RT Caribrod, https://www.youtube.com/watch?v=4EWZTe6f7wc 
16. Uredba o načinu učešća optuženog na glavnom pretresu u krivičnom postupku koji se održava za vreme vanrednog stanja proglašenog 15. marta 2020. godine, "Službeni glasnik RS", broj 49/2020.

17. Ustav Republike Srbije, "Službeni glasnik RS", br. 98/2006.

18. Veljko, Milić. 2020. Skajp suđenja - neophodna ili prenaglašena mera. dostupno na: https://www.autonomija.info/veljko-milic-skajp-sudjenja-neophodna-iliprenaglasena-mera.html 05.07.2020.

19. Worldometer, 2020, https://www.worldometers.info/coronavirus/

20. Zaključak Visokog saveta sudstva, br. 119-05-132/2020-01 od 18. marta 2020.

21. Zaključak Visokog saveta sudstva, br. 021-05-00040/2020-01 od 09.04.2020.

22. Zakonik o krivičnom postupku Republike Srbije, "Službeni glasnik RS", br. 72/2011, 101/2011, 121/2012, 32/2013, 45/2013, 55/2014 i 35/2019.

23. Zoric Jelena, 2020, N1, http://rs.n1info.com/Vesti/a582123/Ministarstvo-pravdezbog-koronavirusa-uvodi-sudjenja-putem-Skajpa.html 